\title{
Sinusoidal Obstruction Syndrome during oxaliplatin based chemotherapy treatment
}

\author{
Oksaliplatin bazlı kemoterapi tedavisi sırasında gelişen Sinuzoidal \\ Obstrüksiyon Sendromu
}

\author{
Erdem Șen, İrem Öner, Özlem Ata \\ Selçuk Üniversitesi Tıp Fakültesi, İç Hastalıkları Ana Bilim Dalı, Tıbbi Onkoloji Bilim Dalı, Konya
}

Dergiye Ulaşma Tarihi: 16.05.2017 Dergiye Kabul Tarihi: 25.04.2018 Doi: 10.5505/aot.2018.63835

ÖZET

Oksaliplatin onkolojide günlük pratiğimizde sık kullanılan kemoterapötik bir ajandır. Oksaliplatin tedavisi ile ilişkili yan etki olarak en s1k nörotoksisite görülmektedir. Nadir olarak oksaliplatin tedavisi karaciğer sinuzoidlerinde venookluziv hastalığa yol açarak obstruksiyona, portal hipertansiyona sebep olabilmektedir. Hastalarda kilo artışı, sağ üst kadran ağrısı, karında asit, hepatik ensafolapti, karaciğer yetmezliği görülebilmektedir. Biz 3. evre kolon kanseri saptanan, adjuvan tedavi olarak kapesitabin ve oksaliplatin tedavisi alan hastamızda gelişen venookluziv hastalık bulgularını, klinik seyrini sunduk.

Anahtar Kelimeler: Oksaliplatin, Sinuzoidal Obstrüksiyon Sendromu, Asit

\begin{abstract}
Oxaliplatin is a commonly used chemotherapeutic agent in our oncology daily practice.Neurotoxicity is the most common side effect associated with oxaliplatin therapy.Rarely, oxaliplatin therapy can cause veno-occlusive disease in the liver sinusoids, leading to obstruction and portal hypertension. Weight gain, right upper quadrant pain, ascites, hepatic insufficiency, liver failure can be seen in patients. We presented a clinical course of venoocclusive disease, which developed in third stage colonic cancer, treated with capecitabine and oxaliplatin as adjuvant treatment.
\end{abstract}

Keywords: Oxaliplatin, Sinusoidal Obstruction Syndrome, Ascites

\section{GíRiş}

Oksaliplatin kolorektal kanser tedavisinde sik kullandığımız platin grubu kemoterapötik ajandır. Neoadjuvan, adjuvan ve metastatik evrede tedavide kullanılmaktadır. Oksaliplatin tedavisi ile iliş̧ili yan etki olarak en sik nörotoksisite karşımıza çıkmaktadır. Bunun dışında bulantı, kusma, ishal, kabızlık, anemi, trombositopeni, hipersensitivite reaksiyonlar1, dispne, dizesteziler oksaliplatin tedavisi ile ilişkili olarak görülebilmektedir. Sinüsoidal Obstrüksiyon Sendromu (SOS) (Veno okluziv hastalık) hepatik venüllerin ve hepatik sinüzoidlerin tıkanmasıyla sonuçlanan küçük hepatik damarlara verilen hasar ile karakterize edilen bir karaciğer hasarı formudur. Patogenezi tam olarak bilinmemekle beraber oksaliplatin bazlı kemoterapi tedavisi ile ilişkili karaciğerde SOS tanımlanmıştır. ${ }^{1}$

Biz evre III kolon kanserli, adjuvan kapesitabin- oksaliplatin kemoterapi tedavisinin 3. Kürü sonunda, oksaliplatin tedavisi ile ilişkili geliştiğini düşündüğümüz SOS toksisitesini sunduk.

\section{OLGU SUNUMU}

55 yaşında bayan hasta dışkılama alışkanlığında değişiklik ve rektal kanama şikayetleri ile gastroenteroloji bölümüne başvurmuş. Yapılan kolonoskopik inceleme 
sonucunda $25 . \mathrm{cm}$ de ülserovejetan kitle saptanmış. Biyopsi sonucunda orta derecede diferansiye adenokarsinom tanısı konulmuş. Yapılan evreleme neticesinde uzak organ metastazı saptanmayan hasta opere edilmiş. Operasyon neticesinde patolojik inceleme sonucunda hasta evre III kolon kanseri olarak kabul edildi. Kardiyak değerlendirmede ejeksiyon fraksiyonu $\% 60$ olarak saptand. Hastaya adjuvan tedavi olarak kapesitabinoksaliplatin tedavisi başlandı. İlk 2 kür sonunda herhangi bir yakınması olamayan hastada 3. kür sonunda karında şişkinlik hissi, erken doyma, sağ üst kadranda dolgunluk hissi şikayetleri ortaya çıktı. Kontrol amaçlı çekilen toraks ve batın BT tetkikinde karaciğer heterojen görünümde idi. Batında orta-ileri derecede asit mevcuttu. Parasentez yapıldı. Hastada portal kaynaklı asit vardı.Karaciğer fonksiyon testlerinde herhangi bir yükseklik mevcut değildi. Portal ve hepatik dopler USG tetkiklerinde tromboz lehine bulgu yoktu. Budd chiari sendromu açısından bakıldığında hepatik ven veya inferior vena cava'da tromboz,oklüzyon saptanmadi. Karaciğer hipoperfüze idi ancak Budd Chiari sendromunda görülebilen kaudat lob hipertrofisi, splenomegali yoktu. Kalp yetmezliği saptanmadı. Tiroid fonksiyon testleri normaldi. Peritoenal karsinomatoza ve proteinüri yoktu. Karaciğer dinamik MR tetkikinde karaciğerde yer kaplayan lezyon saptanmadı. Hastaya karaciğer biyopsisi önerildi ancak hasta yaptırmak istemedi. Yapılan tetkikler birlikte değerlendirildiğinde hastada hepatik sinuzoidlerde veno oklüzyona bağlı SOS düşünüldü (Resim 1,2,3). Hastaya tekrarlayan boşaltıcı parasentezler yapıldı. Asit tedavisi 1 ay süre ile verildi. Adjuvan kemoterapi tedavisi kesildi. 2 ay sonrasında çekilen batın BT'sinde asitin tamamen gerilediği saptandı (Resim 4,5). Hastaya kolon kanseri açısından başka bir tedavi verilmedi. Hastanın kontrolleri halen sorunsuz bir şekilde 1.5 y1ldır devam etmektedir.
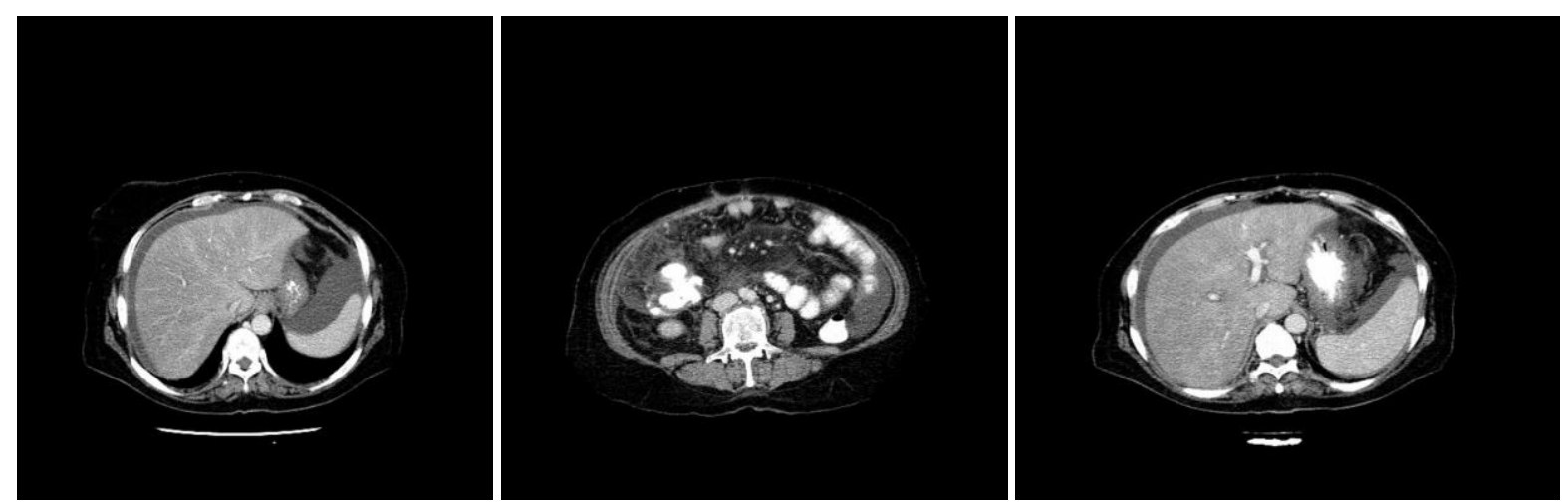

Resim 1,2,3. Tedavisi devam ettiği sırada 3. kür sonu kontrol amaçlı çekilen batın BT görüntüleri. Karaciğer heterojen görünümde, hipoperfüze alanlar mevcuttur. Batın içi ort-ileri derecede asit mevcuttur.
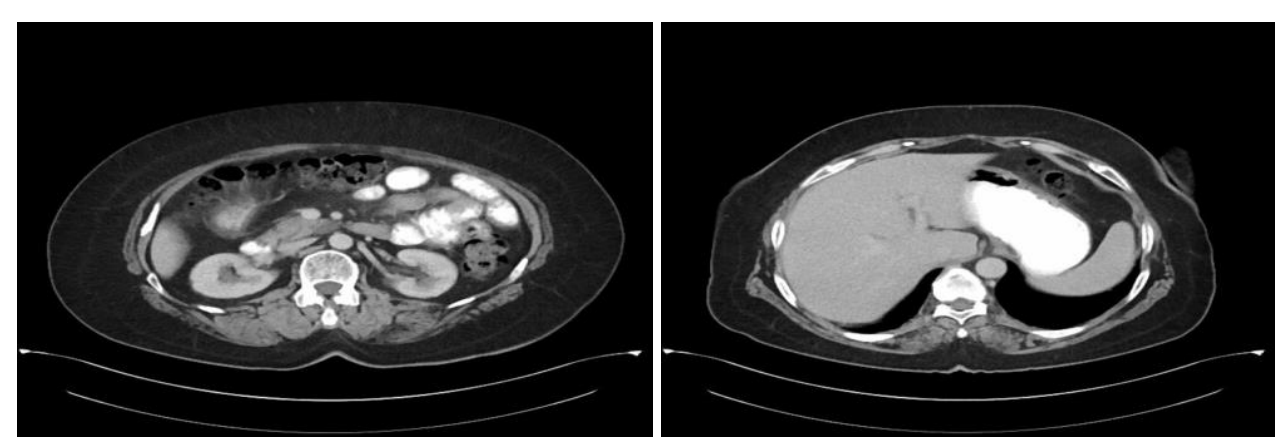

Resim 4, 5. Tedavisi kesildikten 2 ay sonra çekilen batın BT görüntüleri. Asitin tamamen gerilediği görülmektedir. Karaciğerde hipoperfüze alanlar kaybolmuştur.

Adress for correspondence: Erdem Şen Selçuk Üniversitesi Tıp Fakültesi Hastanesi Alaeddin Keykubat Kampüsü Konya - Türkiye 


\section{TARTIŞMA}

SOS tanis1, belirti ve bulgular değerlendirilerek, diğer olas1 nedenleri dışlayarak klinik olarak yapılır. Genellikle ilk başvurulan görüntüleme tetkiki abdominal ultrasonografi (USG) olmaktadır. Batın USG'de asit, hepatomegali, azalmış hepatik akım veya biliyer dilatasyon s1klıkla saptanmaktadır. Portal sistem Doppler incelemesi ile portal kan akımında azalma veya retrograd akım genel olarak geç dönemde ortaya çıkan, bu nedenle tanıdan çok prognoz hakkında bilgi veren bulgulardır. SOS hastalığının tanısını ortaya koymada altın standart yöntem histopatolojik incelemedir. Santral ve sublobuler venlerde subintimal kalınlaşma, konsantrik veya eksentrik lüminal daralmalar patognomonik bulgudur. Erken dönemlerde tromboz belirgin değildir, inflamatuvar hücreler yok veya çok azdır, fakat fragmente eritrosit, ödem ve fibrinojenin neden olduğu belirgin subentotelyal genişleme saptanabilmektedir. Ara dönemde bağ doku artışı ve subintimal lezyonlarda fibrosis gelişir. İleri aşamada ise kronik venöz onstrüksiyon bulguları gözlenir. ${ }^{2}$

SOS patogenezi tam olarak bilinmemektedir. Sinuzoidal endotelyal hücrelerde toksik hasarlanma, matriks metalloproteinaz (MMP) aktivitesinde artış, nitrik oksit sentezinde azalma, sinüzoidal aralıkta eritrosit hakimiyeti, sinusoidal kan akımında azalma ve obstrüksiyon patogenezinde yer aldığı düşünülmektedir. ${ }^{3}$ Bir transmembran ilaç taşıyıcısı ATP7B genindeki polimorfizmler ile oxaliplatin bazlı kemoterapiyi takiben hastalarda gelişen SOS arasında ilişki olabileceği gösterilmiştir ${ }^{4}$. Kombinasyon tedavilerine bevacizumab eklendiğinde SOS görülme sıklığı azaldığı bildirilmiştir. Bevacizumab tedavisi ile MMP miktarının azaldığı bildirilmiştir. ${ }^{5}$
SOS genellikle kök hücre nakillerinde karşımıza çıkan bir klinik antite olmasına rağmen oksaliplatin kullanımına ikincil gelişen SOS olguları karşımıza çıkabilmektedir. Standart ve etkin bir tedavi yaklaşımı bulunmamaktadır. Antikoagülan tedavi, glutamin, Ursodeoksikolik asit, steroid tedavileri verilebilmektedir. Sodyum kısıtlaması ve diüretik tedavi gibi destek tedavileri önemlidir. Onkoloji pratiğinde s1k kullanılan oksaliplatin ile görülebilen bu toksisiteyi sunduk. SOS adjuvan oksaliplatin tedavisi esnasinda hastalık progresyonunun gösterilemediği, asit gelişiminin olduğu hastalarda aklımıza gelmesi gereken klinik bir durum olmalıdır.

\section{Çıkar Çatışması: Yok}

\section{KAYNAKLAR}

1. Rubbia-Brandt L, Audard V, Sartoretti P et al. Severe hepatic sinusoidal obstruction associated with oxaliplatin-based chemotherapy in patients with metastatic colorectal cancer. Ann. Oncol. 2004; 15; 460-466.

2. Helmy A. Review article: updates in the pathogenesis and therapy of hepatic sinusoidal obstruction syndrome. Aliment Pharmacol Ther 2006;23:11-25.

3. Laura Rubbia-Brandt. Sinusoidal Obstruction Syndrome. Clin Liver Dis 2010; 14; 651-668.

4. Robinson SM, Mann J, Manas DM et all. An experimental study to identify the potential role of pharmacogenomics in determining the occurrence of oxaliplatin-induced liver injury. HPB 2013; 15: 581-587.

5. Ribero $\mathrm{D}$, Wuang $\mathrm{H}$, Matteo $\mathrm{D}$ et al. Bevacizumab improves pathologic response and protects against hepatic injury in patients treated with oxaliplatin-based chemotherapy for colorectal liver metastases. Cancer 2007; 110; 2761-2767. 